CLINICAL STUDY

\title{
Identification of insulin secretory defects and insulin resistance during oral glucose tolerance test in a cohort of cystic fibrosis patients
}

\author{
A Battezzati ${ }^{1,2}$, A Mari $^{3}$, L Zazzeron $^{2}$, G Alicandro $^{2}$, L Claut $^{2}$, P M Battezzati $^{4}$ and C Colombo $^{2}$ \\ ${ }^{1}$ International Center for the Assessment of Nutritional Status - DiSTAM, Università degli Studi di Milano, Via Botticelli, 21, 20133 Milan, Italy, \\ ${ }^{2} \mathrm{CF}$ Center, Fondazione IRCCS Ca' Granda, Ospedale Maggiore Policlinico, Università degli Studi di Milano, 20122 Milan, Italy, ${ }^{3}$ C.N.R. Institute of \\ Biomedical Engineering, 35127 Padua, Italy and ${ }^{4}$ Division of Internal Medicine and Liver Unit, San Paolo Hospital School of Medicine, University of Milan, \\ 20142 Milan, Italy
}

(Correspondence should be addressed to A Battezzati at International Center for the Assessment of Nutritional Status - DiSTAM, Università degli Studi di Milano; Email: alberto.battezzati@unimi.it)

\begin{abstract}
Background: Cystic fibrosis (CF)-related diabetes is a leading complication of $\mathrm{CF}$ and is associated with pulmonary and nutritional deterioration, years before an evident hyperglycemia, possibly because of insulin deficiency and resistance.

Aim: To evaluate glucose tolerance, insulin secretion, and insulin sensitivity by a widely applicable method suitable for accurate and prospective measurements in a CF population.

Methods: A total of $165 \mathrm{CF}$ subjects (80 females) aged $17 \pm 5$ years and 18 age- and sex-matched healthy controls $(\mathrm{CON})$ received an oral glucose tolerance test with glucose, insulin and C-peptide determinations. Insulin sensitivity was defined on the basis of glucose and insulin concentrations using the oral glucose insulin sensitivity index, whereas $\beta$-cell function was determined on the basis of a model relating insulin secretion (C-peptide profile) to glucose concentration.

Results: Fifteen percent of CF patients had glucose intolerance and $6 \%$ had diabetes without fasting hyperglycemia and 3\% had diabetes with fasting hyperglycemia. $\beta$-cell function was reduced in $\mathrm{CF}$ patients compared with $\mathrm{CON}\left(70.0 \pm 4.1\right.$ vs $117.9 \pm 11.6 \mathrm{pmol} / \mathrm{min}$ per $\mathrm{m}^{2}$ per $\left.\mathrm{mM}, P<0.001\right)$ and decreased significantly with age by $-2.7 \mathrm{pmol} / \mathrm{min}$ per $\mathrm{m}^{2}$ per $\mathrm{mM}$ per year (confidence interval (CI) -4.5 to -0.82 ), i.e. almost $4 \%$ yearly. The early insulin secretion index was also reduced. Insulin sensitivity was similar to CON. CF patients who attained glucose tolerance comparable to CON had lower $\beta$-cell function and higher insulin sensitivity.

Conclusion: The major alteration in insulin secretion and insulin sensitivity of CF patients is slowly declining $\beta$-cell function, consisting of delayed and reduced responsiveness to hyperglycemia, that in CF patients with normal glucose tolerance may be compensated by an increased insulin sensitivity.
\end{abstract}

European Journal of Endocrinology 165 69-76

\section{Introduction}

Diabetes is an emerging issue in cystic fibrosis (CF) because its prevalence increases with advancing age, affecting the majority of the patients after the age of 40 (1, 2). In addition, CF-related diabetes (CFRD) has negative implications in terms of pulmonary deterioration, observed years before diabetes diagnosis, and mortality (3-10). CFRD prevalence and health consequences are expected to increase in the future as a result of prolonged survival of CF patients.

Alterations in glucose tolerance are characterized by marked glycemic peaks often followed by rapid normalization (11-13). Fasting glycemia is generally lower than in other forms of diabetes and fasting hypoglycemia has been reported (14). Therefore, the categories of 'diabetes without fasting hyperglycemia' (15) and of 'indeterminate glucose tolerance' (isolated hyperglycemia at mid-oral glucose tolerance test (OGTT) or continuous glucose monitoring) were established (16). HbA1c is not sensitive in the diagnosis of CFRD $(17,18)$.

The classic diabetes diagnostic criteria, based on the detection of chronic hyperglycemia (19), were historically aimed at identifying the risk for microvascular complications (9). These are not the primary concern in CFRD. Rather, the impaired nutritional status and deterioration in pulmonary function preceding CFRD may be the consequences of insulin deficiency and insulin resistance $(2,20-23)$. It is currently believed that when the endocrine pancreatic defect progresses beyond a certain threshold, or when insulin resistance arises as a consequence of inflammation or simply because of the endocrine changes of puberty, the absolute or relative insulin deficiency may be responsible for clinical deterioration and eventual CFRD. 
The gold standard technique to measure insulin resistance is the euglycemic insulin clamp. Studies performed with these techniques have shown variable results, with both normal insulin sensitivity (24-27) and insulin resistance for glucose (28-30), protein $(31,32)$, and lipid metabolism (33). These may be related to increased glucose production and gluconeogenesis during fasting $(34,35)$. Heterogeneous data on insulin sensitivity spanning from increased (36), normal $(37,38)$, and decreased $(11,39,40)$ insulin sensitivity were obtained similarly using surrogate techniques.

Using the hyperglycemic clamp, the reference method for glucose-mediated insulin secretion, defects in first- and second-phase insulin secretion were demonstrated (28, $29,41)$. Similar results were obtained with the intravenous glucose tolerance test (IVGTT) technique $(23,39$, 42-44). Both methods are unsuitable for large-scale and repeated assessment. The OGTT is the most common diagnostic test for CFRD and can be repeated yearly. Several studies sampled insulin concentrations during OGTT and analyzed insulin secretion using various algorithms and consistently found reduced and delayed insulin responses $(8,37,45,46)$, even in CF patients with normal glucose tolerance (NGT), supporting the concept that insulin secretory defects are inherent to $\mathrm{CF}$.

Information on insulin secretion obtained during OGTT may be biased by increased hepatic first-pass insulin extraction $(24,25)$, consequent to insulin resistance and modulated by liver disease. Thus, single or integrated measures of insulin concentrations during OGTT may not reflect actual insulin secretion. Furthermore, insulin secretion indexes based on the ratio of insulin to glucose at $30 \mathrm{~min}$ after glucose ingestion could be influenced by a delayed but not absolutely defective secretion. A model-derived calculation of insulin secretion based on the C-peptide profile throughout the OGTT can overcome both difficulties (47).

The aim of this study was therefore to simultaneously evaluate glucose tolerance, insulin sensitivity, and insulin secretion in CF patients by means of insulin and C-peptide profiles measured during OGTT.

\section{Methods}

\section{Subjects}

All CF patients aged $>8$ years in regular follow-up at our center were offered participation in this study during their annual routine care visits if they had been clinically stable in the previous 3 weeks (neither major clinical events including pulmonary exacerbations nor changes in antibiotic or other drugs). Other exclusion criteria were a CFRD diagnosis or insulin or oral hypoglycemic agents received in the previous 6 months. Overall, 165 patients ( 80 females) were considered in this analysis. Healthy volunteers of comparable gender and age distribution ( 8 females and 10 males) were recruited as control group. The most relevant characteristics of the study subjects are reported in Table 1. The study protocol was approved by the Institutional Ethics Committee.

\section{Oral glucose tolerance test}

In all subjects, a standard 3-h OGTT $(1.75 \mathrm{~g} / \mathrm{kg}$, max $75 \mathrm{~g}$ ) was performed, sampling at baseline and at $30 \mathrm{~min}$ intervals plasma glucose, serum insulin, and C-peptide concentrations. Based on fasting and 2-h plasma glucose after OGTT, patients were assigned to one category of glucose tolerance (48): normal, impaired, diabetes without fasting hyperglycemia, or diabetes with fasting hyperglycemia.

\section{Analytical methods}

Plasma glucose was measured on fluoride plasma samples (Gluco-quant; Roche/Hitachi analyzer; Roche Diagnostics) and the other analytes were measured by commercial assays (ECLIA-Cobas C6000 - Roche Diagnostics).

\section{Analysis and modeling of OGTT}

Insulin sensitivity was calculated on the basis of glucose and insulin concentrations using the oral glucose insulin sensitivity (OGIS) index (49). This method is based on a model-derived equation that assesses glucose and insulin concentration at baseline and 90 and 120 min after glucose load.

$\beta$-cell function was evaluated according to a previously published model that represents insulin secretion as the sum of two components $(50,51)$. The first component describes the mean slope of the doseresponse relating insulin secretion (calculated from the C-peptide profile) to glucose concentration during OGTT. This dose-response slope is denoted in the current document as $\beta$-cell function. This slope changes during the OGTT because it is modulated by a potentiation factor, because during an acute stimulation, insulin secretion is higher on the descending phase of hyperglycemia than at the same glucose concentration on the ascending phase. The potentiation factor encompasses several (potentiating) mechanisms (prolonged exposure to hyperglycemia, non-glucose substrates, gastro-intestinal hormones, and neural modulation). It is set to be a positive function of time, and is constrained to average unity during the experiment. In normal subjects, the potentiation factor typically increases from baseline to the end of a 2-h OGTT (47). To quantify this increment, the ratio between the 2-h and the baseline value was calculated. This ratio is denoted as potentiation ratio.

The second component describing insulin secretion represents the dynamic dependence of insulin secretion on the rate of glucose concentration change. This 
Table 1 Clinical features and glucose tolerance during oral glucose tolerance test of the study groups. Height, weight, and BMI SDS: (SDS according to data published in Ref. (59)).

\begin{tabular}{|c|c|c|c|}
\hline & CF & CON & $P$ value ${ }^{*}$ \\
\hline No. of subjects & 165 & 18 & \\
\hline Age (years) (mean \pm s.D.) & $17.0 \pm 5.4$ & $18.7 \pm 4.9$ & 0.119 \\
\hline Male gender $n(\%)$ & $85(51.5)$ & $10(55.6)$ & \\
\hline$\Delta$ F508 homozygous $n(\%)$ & 50 (30.3) & - & \\
\hline$\Delta \mathrm{F} 508$ heterozygous $n(\%)$ & $73(44.2)$ & - & \\
\hline Other $n(\%)$ & $28(17.0)$ & - & \\
\hline Unknown $n(\%)$ & $14(8.5)$ & - & \\
\hline Pancreatic insufficiency $n(\%)$ & $135(81.8)$ & 0 & \\
\hline Liver disease $n(\%)$ & $33(20.0)$ & 0 & \\
\hline Pseudomonas aeruginosa $n(\%)$ & $120(72.7)$ & 0 & \\
\hline Burkholderia cepacia complex $n(\%)$ & $12(7.3)$ & 0 & \\
\hline Liver transplantation $n(\%)$ & $5(3.0)$ & 0 & \\
\hline Pulmonary transplantation $n(\%)$ & $3(1.8)$ & 0 & \\
\hline Permanent 02 therapy $n(\%)$ & $6(3.6)$ & 0 & \\
\hline Height SDS (mean \pm S.D.) & $-0.67 \pm 1.08$ & $0.24 \pm 1.40$ & 0.002 \\
\hline Weight SDS (mean \pm s.D.) & $-0.54 \pm 1.02$ & $-0.04 \pm 1.06$ & \\
\hline BMI SDS (mean \pm S.D.) & $-0.26 \pm 1.04$ & $0.05 \pm 1.14$ & \\
\hline PCR (mg/dl) & $10.1 \pm \overline{12.8}$ & - & \\
\hline $\mathrm{HbA1c}(\%)$ & $5.8 \pm 0.8$ & $5.4 \pm 0.4$ & 0.016 \\
\hline FEV1 ( $\%$ of predicted) & $79.8 \pm 24.3$ & - & \\
\hline FVC ( $\%$ of predicted) & $87.2 \pm 19.3$ & - & \\
\hline Pancreatic insufficiency $n(\%)$ & $135(82)$ & _ & \\
\hline Normo-tolerant $n(\%)$ & $125(76)$ & $18(100)$ & \\
\hline Glucose intolerant $n(\%)$ & $25(15)$ & - & \\
\hline Diabetes without fasting hyperglycemia $n(\%)$ & $5(3)$ & - & \\
\hline Diabetes with fasting hyperglycemia $n(\%)$ & $10(6)$ & - & \\
\hline
\end{tabular}

*Only $P$ values $<0.20$ are reported.

component is related to early insulin release and is denoted as early insulin secretion index.

The model parameters were estimated from glucose and C-peptide concentrations by regularized leastsquares, as previously described $(50,51)$. Regularization involves the choice of smoothing factors selected to obtain glucose and C-peptide model residuals with S.D. close to the expected measurement error $(\sim 1 \%$ for glucose and $\sim 4 \%$ for $\mathrm{C}$-peptide). Insulin secretion rates were calculated from the model every $5 \mathrm{~min}$. The integral of insulin secretion during the 2-h OGTT was denoted as total insulin output.

\section{Statistical analysis}

Statistical analysis was performed by means of PASW statistics 18 software. Comparisons of means were performed by means of Student's $t$-test for paired or unpaired data, or by non-parametric tests when appropriate. Data were log-normalized when necessary. The relationship among variables was performed by means of regression analysis. The comparison of proportions was performed by means of $\chi^{2}$ test.

\section{Results}

Glucose tolerance distribution in $\mathrm{CF}$ and control subjects is shown in Table 1 . The mean glucose concentrations during OGTT, providing a continuous measure of glucose tolerance, and the insulin and C-peptide concentrations are reported in Table 2 as median and interquartile ranges.

Glucose concentrations of CF subjects were similar to controls $(\mathrm{CON})$ at basal and increased at $2 \mathrm{~h}$. The mean OGTT glucose concentration was increased in CF subjects (mean \pm s.E.M. $128 \pm 3$ vs $90 \pm 4 \mathrm{mg} / \mathrm{dl}$, $P<0.01)$. In contrast, basal and 2-h insulin and C-peptide concentrations were similar to CON. The 2-h glucose, insulin, and C-peptide concentrations increased in the higher quartiles of mean OGTT glucose concentration.

Insulin secretion was delayed in CF patients, who achieved an insulin peak concentration similar to CON $(436 \pm 24$ vs $314 \pm 40 \mathrm{pmol} / \mathrm{l}, P=\mathrm{NS})$, but later after glucose ingestion $18,28,35$, and $18 \%$ of CF subjects peaked at $30,60,90$, and $120 \mathrm{~min}$, respectively, compared with $39,28,0$, and $33 \%$ of $\operatorname{CON}\left(\chi^{2} P<0.01\right)$.

Pancreatic insufficient CF patients had similar distribution of glucose tolerance categories as pancreatic sufficient patients, despite increased mean OGTT glucose concentration (134 \pm 6 vs $104 \pm 6 \mathrm{mg} / \mathrm{dl})$ and decreased fasting and 30-min insulin (41 \pm 10 vs $72 \pm 10$ and $198 \pm 49$ vs $423 \pm 49 \mathrm{pmol} / \mathrm{l})$ and C-peptide (0.50 \pm 0.07 vs $0.63 \pm 0.03$ and $1.20 \pm 0.17$ vs 2.00 $\pm 0.17 \mathrm{nmol} / \mathrm{l})$ concentrations $(P<0.001$ for all parameters).

$\beta$-cell parameters are reported in Table 2. $\beta$-cell function was reduced in CF compared with CON subjects (mean \pm s.e.M. $70.0 \pm 4.1$ vs $117.9 \pm 11.6 \mathrm{pmol} / \mathrm{min}$ 


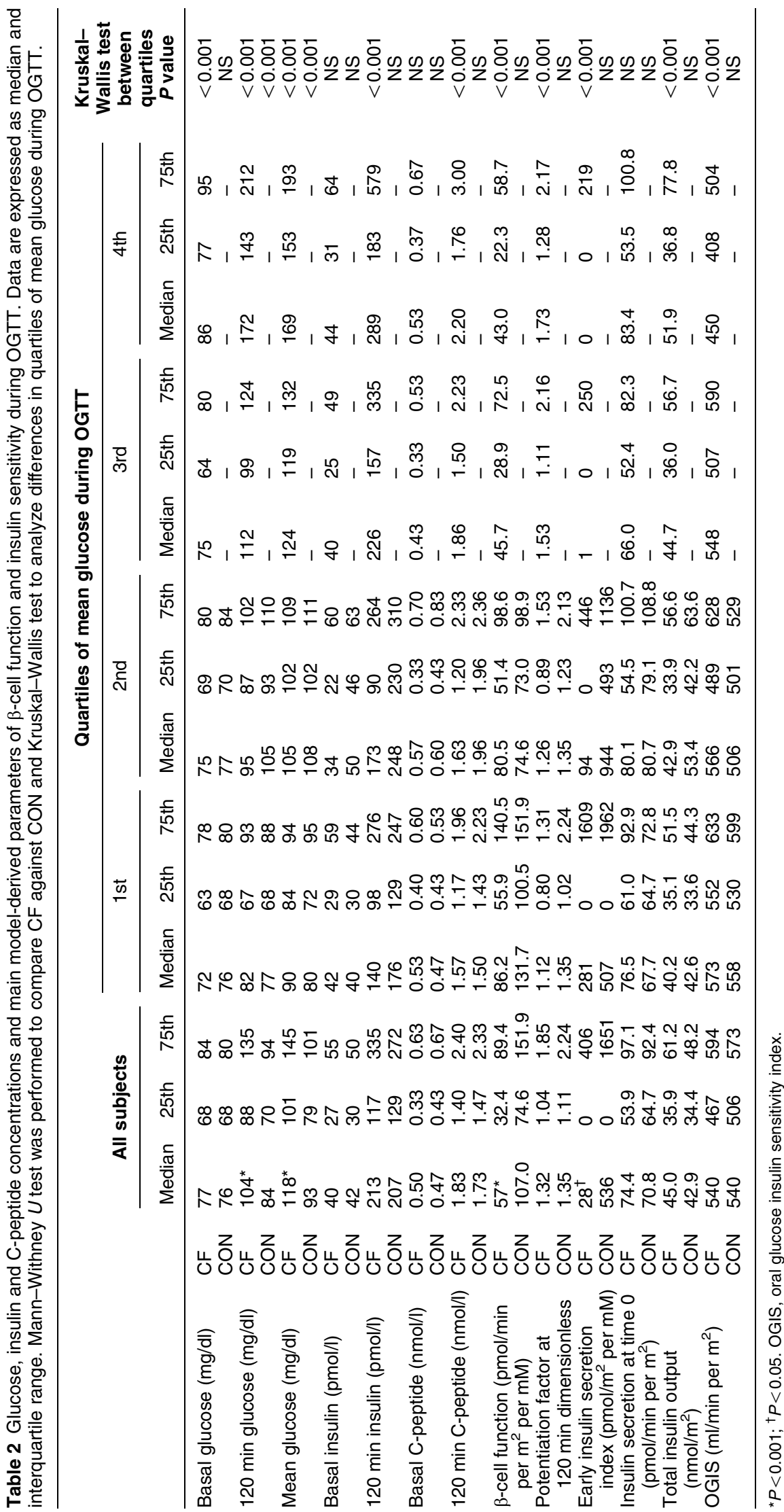


per $\mathrm{m}^{2}$ per $\left.\mathrm{mM}, P<0.001\right)$. This tended to decrease with increasing quartiles of mean OGTT glucose concentrations. The frequency distribution of $\beta$-cell function (log-normalized data) is shown in Fig. 1 (panel A).

$\beta$-cell function declined significantly with age in $\mathrm{CF}$ but not in CON subjects. To avoid a selection bias due to diabetes-free long survivors, the regression analysis of $\beta$-cell function dependence on age was performed in patients younger than 25 years, as reported in Fig. 2 for both genders. The slope of $\beta$-cell function decline was $-2.7 \mathrm{pmol} / \mathrm{min}$ per $\mathrm{m}^{2}$ per $\mathrm{mM}(\mathrm{CI}-4.5$ to -0.82$)$ each year, i.e. almost $4 \%$ per year. The potentiation factor for insulin secretion at $120 \mathrm{~min}$, known to modulate $\beta$-cell function, was not different in $\mathrm{CF}$ and $\mathrm{CON}$ subjects. It increased with increasing quartiles of mean OGTT glucose concentrations, but did not show any dependence on age.

The early insulin secretion index was lower in CF, tended to decrease with increasing quartiles of mean OGTT glucose concentrations, and did not show any dependence on age.

Baseline fasting insulin secretion was similar in $\mathrm{CF}$ and CON subjects and between quartiles of mean OGTT
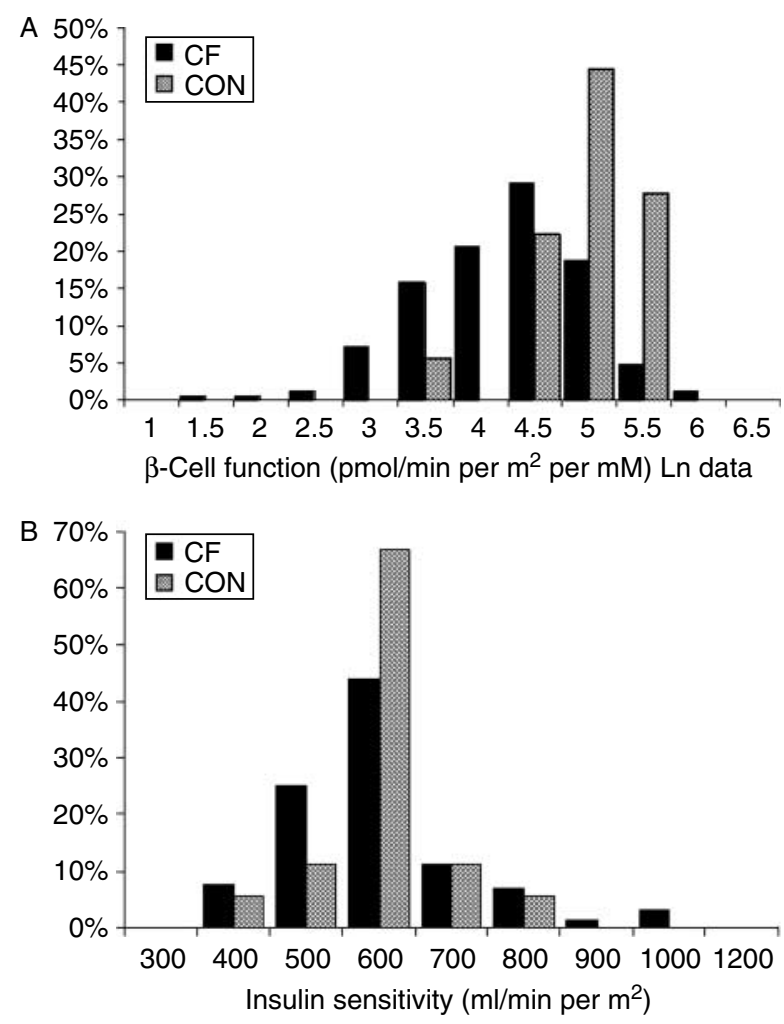

Figure 1 (Panel A) Frequency distribution of $\beta$-cell function (the slope of the dose-response relating insulin secretion to glucose concentration) during OGTT in CF and CON. The data have been log-normalized. The distribution in CF is skewed to the left compared with $\mathrm{CON}$, consequently $\beta$-cell function is lower in $\mathrm{CF}$ than in CON. (Panel B) Frequency distribution of insulin sensitivity during OGTT in CF and CON. The distributions were not significantly different in the two groups.

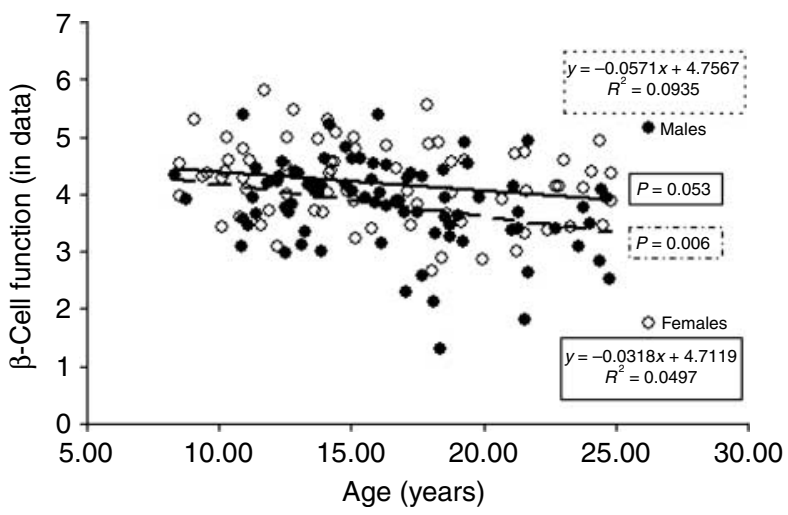

Figure 2 Regression analysis of $\beta$-cell function dependence on age in CF individuals younger than 25 years. The data have been log-normalized. $\beta$-cell function declined significantly with age in $\mathrm{CF}$ by $\sim 4 \%$ each year.

glucose concentration. Total insulin output was also similar between $\mathrm{CF}$ and $\mathrm{CON}$ subjects although it increased with increasing quartiles of mean OGTT glucose concentration.

Pancreatic insufficient $C F$ patients had reduced $\beta$-cell function $(62.2 \pm 9.8$ vs $104.8 \pm 10.9, \quad P<0.001)$, potentiation factor at $120 \mathrm{~min}(1.29 \pm 0.08$ vs 1.75 $\pm 0.07, P=0.012$ ), and early insulin secretion index $(268 \pm 511$ vs $1357 \pm 508, P<0.001)$, but a similar total insulin output compared with those with pancreatic sufficiency.

Insulin sensitivity measured by OGIS was similar in $\mathrm{CF}$ and $\mathrm{CON}$ subjects $(552 \pm 10$ vs $543 \pm 17 \mathrm{ml} / \mathrm{min}$ per $\left.\mathrm{m}^{2}, P=0.781\right)$, but it decreased with increasing quartiles of mean OGTT glucose concentrations and it was unaffected by gender, age, and pancreatic status. The frequency distribution of insulin sensitivity in $\mathrm{CF}$ and CON subjects is shown in Fig. 1 (panel B).

The relationship of $\beta$-cell function and insulin sensitivity in determining glucose tolerance according to the quartiles of mean OGTT glucose concentration is shown in Fig. 3. CF patients who attained glucose tolerance comparable to $\mathrm{CON}$ (the lower 2 quartiles of mean OGTT glucose concentration) had lower $\beta$-cell function but similar or higher insulin sensitivity than CON.

\section{Discussion}

In a large population of CF patients, we applied an OGTT model to measure insulin secretion and insulin sensitivity. We also quantified the two defective components of insulin secretion in $\mathrm{CF}$ subjects, i.e. the delay and the reduction in $\beta$-cell responses to glucose, providing parameters suitable for comparison among research groups and evaluation for predictiveness of future diabetes development.

Our main findings are: i) $\beta$-cell function is impaired even in CF patients with NGT, specifically with regard to 


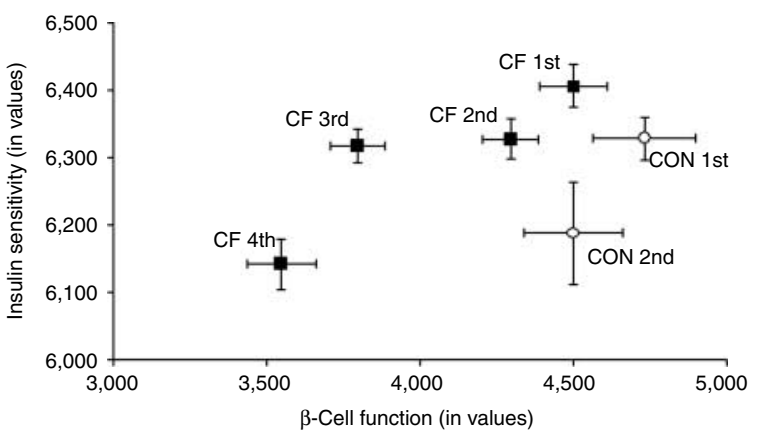

Figure 3 Mean values of log-normalized $\beta$-cell function and insulin sensitivity were calculated in CF and CON for each of the quartiles of mean OGTT glucose concentrations (an index of glucose tolerance) in the two groups pooled. CON showed mean OGTT glucose concentrations exclusively in the two lowest quartiles of the distribution. The figure shows that corresponding degrees of glucose tolerance were obtained in CF with greater insulin sensitivity and lower $\beta$-cell function than in CON.

the insulin secretion increment for a given glucose concentration increment; early insulin secretion index is also impaired, with reduced ability to increase insulin secretion in response to the speed of glucose increment after glucose ingestion. Both defects contribute to deterioration of glucose tolerance in $\mathrm{CF}$ patients. ii) Despite defective $\beta$-cell function, during OGTT the insulin output may eventually increase to levels comparable to CON. iii) Insulin sensitivity may be increased and compensate for defective $\beta$-cell function in CF patients with NGT; when defective, however, it is a determinant of glucose intolerance. iv) The defect in $\beta$-cell function worsens with age at $\sim 4 \%$ per year.

Our results substantially agree with recent studies that assessed insulin secretion during OGTT using various algorithms and consistently found reduced and delayed insulin responses. However, quantitative aspects may not be comparable $(8,37,40,46)$. The largest available adult series (37) displayed an average $\beta$-cell function as $70 \%$ of control values in the whole CF population and $50 \%$ of control values in the subgroup with NGT. $\beta$-Cell function was measured by the insulinogenic index (ratio between the 30-min increments in plasma insulin and glucose concentrations), thus it could not discriminate between a secretion delay and absolute secretory defect. In our series, the insulin peak was significantly delayed in CF patients although one-third of CON subjects peaked in the second hour as well. Thus, delay alone was not an appropriate discriminatory factor from normal. Model-derived parameters provided quantitative measures capable to better characterize the defects inherent to $\beta$-cell function in $\mathrm{CF}$ patients and indicated that insulin secretion in response to glucose was consistently reduced to $60 \%$ of CON independently from the secretory delay.

In another study (40), the insulinogenic index of children with CF was $90 \%$ decreased, whereas the insulin area under the curve (AUC) was only $30-50 \%$ decreased compared with CON. Thus, secretory delay and absolute secretion were considered distinct factors, both affecting glucose tolerance. However, in our series, hyperglycemia could stimulate total insulin output (and insulin and C-peptide AUCs) to levels similar or even greater than CON. This finding has practical implications, because the absolute insulin secretion rates or the insulin or C-peptide concentrations or AUCs may not accurately describe $\beta$-cell function defects.

We found that CF patients with NGT may compensate a decreased $\beta$-cell function with an intact or increased insulin sensitivity. Animal models showed that reduced insulin secretion increases insulin sensitivity until hyperglycemia arises $(52,53)$. In humans, we found that chronic hyperinsulinemia in insulinoma causes insulin resistance (54), whereas insulin secretory defects in pancreatic surgery initially increase insulin sensitivity (55). The results of the present study suggest that in many CF patients, an increased insulin sensitivity consequent to hypoinsulinemia may mask the insulin secretory defect, producing NGT. This unstable equilibrium may be easily disrupted when insulin sensitivity decreases because of infection or growth spurts-related endocrine changes, and causing initially transient and lately stable glucose intolerance and diabetes.

Insulin sensitivity measures in CF patients, although skewed towards lower values, were distributed over a wider range compared with $\mathrm{CON}$ and were not significantly related to age. Even though recent pulmonary exacerbations, IV antibiotics, steroid treatment, and insulin therapy were exclusion criteria, other factors such insulinopenia, hypoxia secondary to lung disease (29), chronic inflammation (56), and puberty (57) could have affected insulin sensitivity.

In an earlier preliminary study, we suggested that the individual changes in glucose tolerance in repeated OGTT tests were due to changes in insulin sensitivity rather than changes in $\beta$-cell function, which appeared to be more stable over time (58). However, it is generally assumed that increasing CFRD prevalence with age is related to progressive deterioration of pancreatic function, but the formal demonstration is currently lacking. In the current, larger study, we were able to demonstrate that the decrement in $\beta$-cell function is age-related, fully supporting the above concept, and providing the rough estimate of a $3-4 \%$ yearly rate of decrement. Further validation will be needed from prospective assessments of $\beta$-cell function in studies with adequate sample size and duration, involving also older CF populations.

In conclusion, we quantified several defects in $\beta$-cell function, in both total and early insulin secretion in CF patients. Increased insulin sensitivity may compensate for the $\beta$-cell function defects, producing NGT. Hyperglycemia during OGTT may eventually stimulate a delayed insulin secretion to absolute rates comparable to CON. However, the secretory defects progress 
with age. Accurate, large scale, and prospective measurements of $\beta$-cell function and insulin resistance can be obtained by modeling C-peptide and insulin concentrations during OGTT tests.

\section{Declaration of interest}

The authors declare that there is no conflict of interest that could be perceived as prejudicing the impartiality of the research reported.

\section{Funding}

The study is supported by a grant from Italian Cystic Fibrosis Research Foundation - ONLUS (Prog. FFC \#16/2005).

\section{Author contribution statement}

Study concept and design: A Battezzati and C Colombo. Analysis and interpretation of data: G Alicandro, A Battezzati, P M Battezzati, C Colombo. Acquisition of data: G Alicandro, A Battezzati, L Claut C Colombo, L Zazzeron. Modelling: A Mari. Drafting of the manuscript: A Battezzati and C Colombo. Critical revision of the manuscript for important intellectual content: A Battezzati and Colombo C.

\section{References}

1 Cystic Fibrosis Foundation Patient Registry. 2008 Annual Data Report Bethesda, MD, 2009 Cystic Fibrosis Foundation.

2 Lanng S, Hansen A, Thorsteinsson B, Nerup J \& Koch C. Glucose tolerance in patients with cystic fibrosis: five-year prospective study. BMJ $1995311655-659$.

3 Finkelstein SM, Wielinski CL, Elliott GR, Warwick WJ, Barbosa J, Wu SC \& Klein DJ. Diabetes mellitus associated with cystic fibrosis. Journal of Pediatrics 1988112 373-377. (doi:10.1016/S00223476(88)80315-9)

4 Lanng S, Thorsteinsson B, Nerup J \& Koch C. Influence of the development of diabetes mellitus on clinical status in patients with cystic fibrosis. European Journal of Pediatrics $1992151684-687$. (doi:10.1007/BF01957574)

5 Lanng S, Thorsteinsson B, Nerup J \& Koch C. Diabetes mellitus in cystic fibrosis: effect of insulin therapy on lung function and infections. Acta Paediatrica 199483 849-853. (doi:10.1111/j. 1651-2227.1994.tb13156.x)

6 Milla CE, Warwick WJ \& Moran A. Trends in pulmonary function in patients with cystic fibrosis correlate with the degree of glucose intolerance at baseline. American Journal of Respiratory and Critical Care Medicine 2000162 891-895.

7 Marshall BC, Butler SM, Stoddard M, Moran AM, Liou TG \& Morgan WJ. Epidemiology of cystic fibrosis-related diabetes. Journal of Pediatrics 2005146 681-687. (doi:10.1016/j.jpeds. 2004.12.039)

8 Bismuth E, Laborde K, Taupin P, Velho G, Ribault V, Jennane F, Grasset E, Sermet I, de Blic J, Lenoir G \& Robert JJ. Glucose tolerance and insulin secretion, morbidity, and death in patients with cystic fibrosis. Journal of Pediatrics 2008152 540-545. (doi:10.1016/j.jpeds.2007.09.025)

9 Chamnan P, Shine BS, Haworth CS, Bilton D \& Adler AI. Diabetes as a determinant of mortality in cystic fibrosis. Diabetes Care 2010 33 311-316. (doi:10.2337/dc09-1215)

10 Hameed S, Morton JR, Jaffé A, Field PI, Belessis Y, Yoong T, Katz T \& Verge CF. Early glucose abnormalities in cystic fibrosis are preceded by poor weight gain. Diabetes Care 201033 221-226. (doi:10.2337/dc09-1492)

11 Costa M, Potvin S, Hammana I, Malet A, Berthiaume Y, Jeanneret A, Lavoie A, Ĺvesque R, Perrier J, Poisson D, Karelis AD, Chiasson JL \& Rabasa-Lhoret R. Increased glucose excursion in cystic fibrosis and its association with a worse clinical status. Journal of Cystic Fibrosis 20076 376-383. (doi:10.1016/j. jcf.2007.02.005)

12 Jefferies C, Solomon M, Perlman K, Sweezey N \& Daneman D. Continuous glucose monitoring in adolescents with cystic fibrosis. Journal of Pediatrics 2005147 396-398. (doi:10.1016/j.jpeds. 2005.05.004)

13 Lanng S, Thorsteinsson B, Erichsen G, Nerup J \& Koch C. Glucose tolerance in cystic fibrosis. Archives of Disease in Childhood 199166 612-616. (doi:10.1136/adc.66.5.612)

14 Battezzati A, Battezzati PM, Costantini D, Seia M, Zazzeron L, Russo MC, Daccò V, Bertoli S, Crosignani A \& Colombo C. Spontaneous hypoglycemia in patients with cystic fibrosis. European Journal of Endocrinology 2007156 369-376. (doi:10. 1530/eje.1.02344)

15 Moran A, Hardin D, Rodman D, Allen HF, Beall RJ, Borowitz D, Brunzell C, Campbell PW, Chesrown SE, Duchow C, Fink RJ, FitzSimmons SC, Hamilton N, Hirsch I, Howenstine MS, Klein DJ, Madhun Z, Pencharz PB, Quittner AL, Robbins MK, Schindler T, Schissel K, Schwarzenberg SJ, Stallings VA, Tullis DE \& Zipf WB. Diagnosis, screening, and management of CFRD: a consensus conference report. Diabetes Research and Clinical Practice 199945 55-71. (doi:10.1016/S0168-8227(99)00058-3)

16 O'Riordan SM, Dattani MT \& Hindmarsh PC. Cystic fibrosis-related diabetes in childhood. Hormone Research in Paediatrics 201073 15-24. (doi:10.1159/000271912)

17 Brennan AL, Gyi KM, Wood DM, Hodson ME, Geddes DM \& Baker EH. Relationship between glycosylated haemoglobin and mean plasma glucose concentration in cystic fibrosis. Journal of Cystic Fibrosis 20065 27-31.

18 Dobson L, Sheldon CD \& Hattersley AT. Conventional measures underestimate glycaemia in cystic fibrosis patients. Diabetic Medicine 200421 691-696. (doi:10.1111/j.1464-5491.2004. 01219.x)

19 Bennett PH, Burch TA \& Miller M. Diabetes mellitus in American (Pima) Indians. Lancet 19712 125-128. (doi:10.1016/S01406736(71)92303-8)

20 Dobson L, Sheldon CD \& Hattersley AT. Understanding cysticfibrosis-related diabetes: best thought of as insulin deficiency? Journal of the Royal Society of Medicine 200497 26-35. (doi:10. $1258 /$ jrsm.97.1.26)

21 O'Riordan SM, Robinson PD, Donaghue KC, Moran A \& the ISPAD Clinical Practice Consensus. Management of cystic fibrosis related diabetes. Pediatric Diabetes 20089 338-344. (doi:10.1111/ j.1399-5448.2008.00437.x)

22 Hardin DS, Leblanc A, Marshall G \& Seilheimer DK. Mechanisms of insulin resistance in cystic fibrosis. American Journal of Physiology. Endocrinology and Metabolism 2001281 1022-1028.

23 Moran A, Diem P, Klein DJ, Levitt MD \& Robertson RP. Pancreatic endocrine function in cystic fibrosis. Journal of Pediatrics 1991118 715-723. (doi:10.1016/S0022-3476(05)80032-0)

24 Ahmad T, Nelson R \& Taylor R. Insulin sensitivity and metabolic clearance rate of insulin in cystic fibrosis. Metabolism $1994 \mathbf{4 3}$ 163-167. (doi:10.1016/0026-0495(94)90239-9)

25 Lanng S, Thorsteinsson B, Røder ME, Nerup J \& Koch C. Insulin sensitivity and insulin clearance in cystic fibrosis patients with normal and diabetic glucose tolerance. Clinical Endocrinology 1994 41 217-223. (doi:10.1111/j.1365-2265.1994.tb02533.x)

26 Cucinotta D, Conti Nibali S, Arrigo T, Di Benedetto A, Magazzù G, Di Cesare E, Costantino A, Pezzino V \& De Luca F. Beta cell function, peripheral sensitivity to insulin and islet cell autoimmunity in cystic fibrosis patients with normal glucose tolerance. Hormone Research 199034 33-38. (doi:10.1159/000181792)

27 Cucinotta D, De Luca F, Gigante A, Arrigo T, Di Benedetto A, Tedeschi A, Lombardo F, Romano G \& Sferlazzas C. No changes of insulin sensitivity in cystic fibrosis patients with different degrees of glucose tolerance: an epidemiological and longitudinal study. European Journal of Endocrinology 1994130 253-258. (doi:10. 1530/eje.0.1300253)

28 Austin A, Kalhan SC, Orenstein D, Nixon P \& Arslanian S. Roles of insulin resistance and beta-cell dysfunction in the pathogenesis 
of glucose intolerance in cystic fibrosis. Journal of Clinical Endocrinology and Metabolism 1994 79 80-85. (doi:10.1210/jc. 79.1.80)

29 Moran A, Pyzdrowski KL, Weinreb J, Kahn BB, Smith SA, Adams KS \& Seaquist ER. Insulin sensitivity in cystic fibrosis. Diabetes 199443 1020-1026. (doi:10.2337/diabetes.43.8.1020)

30 Hardin DS, LeBlanc A, Lukenbough S \& Seilheimer DK. Insulin resistance is associated with decreased clinical status in cystic fibrosis. Journal of Pediatrics 1997130 948-956. (doi:10.1016/ S0022-3476(97)70282-8)

31 Hardin DS, LeBlanc A, Lukenbaugh S, Para L \& Seilheimer DK. Proteolysis associated with insulin resistance in cystic fibrosis. Pediatrics 1998101 433-437. (doi:10.1542/peds.101.3.433)

32 Moran A, Milla C, Ducret R \& Nair KS. Protein metabolism in clinically stable adult cystic fibrosis patients with abnormal glucose tolerance. Diabetes 200150 1336-1343. (doi:10.2337/ diabetes.50.6.1336)

33 Moran A, Basu R, Milla C \& Jensen MD. Insulin regulation of free fatty acid kinetics in adult cystic fibrosis patients with impaired glucose tolerance. Metabolism 200453 1467-1472. (doi:10. 1016/j.metabol.2004.06.015)

34 Hardin DS, LeBlanc A, Para L \& Seilheimer DK. Hepatic insulin resistance and defects in substrate utilization in cystic fibrosis. Diabetes 199948 1082-1087. (doi:10.2337/diabetes.48.5.1082)

35 Hardin DS, Ahn C, Rice J, Rice M \& Rosenblatt R. Elevated gluconeogenesis and lack of suppression by insulin contribute to cystic fibrosis-related diabetes. Journal of Investigative Medicine 200856 567-573. (doi:10.231/JIM.Ob013e3181671788)

36 Wilmshurst EG, Soeldner JS, Holsclaw DS, Kaufmann RL, Shwachman H, Aoki TT \& Gleason RE. Endogenous and exogenous insulin responses in patients with cystic fibrosis. Pediatrics $1975 \mathbf{5 5} 75-82$.

37 Yung B, Noormohamed FH, Kemp M, Hooper J, Lant AF \& Hodson ME. Cystic fibrosis-related diabetes: the role of peripheral insulin resistance and beta-cell dysfunction. Diabetic Medicine 200219 221-226. (doi:10.1046/j.1464-5491.2002.00666.x)

38 Preumont V, Lebecque P, Hermans MP \& Buysschaert M. Glucose homeostasis and genotype-phenotype interplay in cystic fibrosis patients with CFTR gene DF508 mutation. Diabetes Care 200730 1187-1192. (doi:10.2337/dc06-1915)

39 Tofe S, Moreno JC, Maiz L, Alonso M, Escobar H \& Barrio R. Insulin secretion abnormalities and clinical deterioration related to impaired glucose tolerance in cystic fibrosis. European Journal of Endocrinology 2005152 241-247. (doi:10.1530/eje.1.01836)

40 Elder DA, Wooldridge JL, Dolan M \& D'Alessio D. Glucose tolerance, insulin secretion and insulin sensitivity in children and adolescents with cystic fibrosis and no prior history of diabetes. Journal of Pediatrics 2007151 653-658. (doi:10.1016/j. jpeds.2007.05.012)

41 Rakotoambinina B, Delaisi B, Laborde K, Silly C, De Blic J, Lenoir G \& Robert JJ. Insulin responses to intravenous glucose and the hyperglycemic clamp in cystic fibrosis patients with different degrees of glucose tolerance. Pediatric Research 199436 667-671. (doi:10.1203/00006450-199411000-00024)

42 Hinds A, Sheehan AG \& Parsons HG. Tolbutamide causes a modest increase in insulin secretion in cystic fibrosis patients with impaired glucose tolerance. Metabolism $1995 \quad 44$ 13-18. (doi:10.1016/0026-0495(95)90283-X)

43 Holl RW, Heinze E, Wolf A, Rank M \& Teller WM. Reduced pancreatic insulin release and reduced peripheral insulin sensitivity contribute to hyperglycaemia in cystic fibrosis. European Journal of Pediatrics $1995154 \quad 356-361 . \quad$ (doi:10.1007/ BF02072102)

44 Garagorri JM, Rodríguez G, Ros L \& Sánchez A. Early detection of impaired glucose tolerance in patients with cystic fibrosis and predisposition factors. Journal of Pediatric Endocrinology $\mathcal{E}$ Metabolism 200114 53-60. (doi:10.1515/JPEM.2001.14.1.53)
45 Ripa P, Robertson I, Cowley D, Harris M, Masters IB \& Cotterill AM The relationship between insulin secretion, the insulin-like growth factor axis and growth in children with cystic fibrosis. Clinical Endocrinology 200256 383-389. (doi:10.1046/j.1365-2265. 2002.01484.x)

46 Mohan K, Miller H, Dyce P, Grainger R, Hughes R, Vora J, Ledson M \& Walshaw M. Mechanisms of glucose intolerance in cystic fibrosis. Diabetic Medicine 200926 582-588. (doi:10.1111/ j.1464-5491.2009.02738.x)

47 Mari A \& Ferrannini E. Beta-cell function assessment from modelling of oral tests: an effective approach. Diabetes, Obesity and Metabolism 2008 10 77-87. (doi:10.1111/j.1463-1326. 2008.00946.x)

48 Rosenstein BJ \& Cutting GR. The diagnosis of cystic fibrosis: a consensus statement cystic fibrosis consensus panel. Journal of Pediatrics 1998132 589-595. (doi:10.1016/S0022-3476(98) 70344-0)

49 Mari A, Pacini G, Murphy E, Ludvik B \& Nolan JJ. A model-based method for assessing insulin sensitivity from the oral glucose tolerance test. Diabetes Care 200124 539-548. (doi:10.2337/ diacare.24.3.539)

50 Mari A, Tura A, Gastaldelli A \& Ferrannini E. Assessing insulin secretion by modeling in multiple-meal tests: role of potentiation. Diabetes 200251 S221-S226. (doi:10.2337/diabetes.51.2007. S221)

51 Mari A, Schmitz O, Gastaldelli A, Oestergaard T, Nyholm B \& Ferrannini E. Meal and oral glucose tests for the assessment of $\beta$-cell function: modeling analysis in normal subjects. American Journal of Physiology. Endocrinology and Metabolism $20022 \mathbf{2 8 3}$ E1159-E1166. (doi:10.1152/ajpendo.00093.2002)

52 Shi ZQ, Giacca A, Fisher SJ, Lekas M, Bilinski D, Van Delangeryt M, Lickley HL \& Vranic M. Indirect effects of insulin in regulating glucose fluxes. Advances in Experimental Medicine and Biology 1993 334 151-168.

53 Barron PP, Goobi J, Davies S, Pye S \& Radziuk J. Hemipancreatectomy, peripheral diversion of pancreatic venous drain-age, and insulin sensitivity. Transplantation Proceedings 199527 3040-3041.

54 Battezzati A, Terruzzi I, Perseghin G, Bianchi E, Di Carlo V, Pozza G \& Luzi L. Defective insulin action on protein and glucose metabolism during chronic hyperinsulinaemia in subjects with benign insulinoma. Diabetes $1995 \mathbf{4 4} 837-844$. (doi:10.2337/ diabetes.44.7.837)

55 Battezzati A, Zerbi A, Perseghin G, Caumo A, Terruzzi I, Di Carlo V \& Luzi L. Effect of hemipancreatectomy and of pancreatic diversion on the tolerance to a glucose load in humans. European Journal of Clinical Investigation 200030 397-410. (doi:10.1046/j.13652362.2000.00648.x)

56 Battezzati A, Mari A, Costantini D, Zazzeron L, Russo C \& Colombo C. Contribution of defects in insulin sensitivity and betacell function to the changes over time in the glucose tolerance of cystic fibrosis patients. Pediatric Pulmonology 200641 391-392. (doi:10.1002/ppul.20400)

57 Olefsky JM \& Glass CK. Macrophages, inflammation, and insulin resistance. Annual Review of Physiology $2010 \quad 17$ 219-246. (doi:10.1146/annurev-physiol-021909-135846)

58 Caprio S, Amiel SA, Merkel P \& Tamborlane WV. Insulin-resistant syndromes in children. Hormone Research 199339 112-114. (doi:10.1159/000182796)

59 de Onis M \& Onyango A. The Centers for Disease Control and Prevention 2000 growth charts and the growth of breastfed infants. Acta Paediatrica 200392 413-419. (doi:10.1111/j.16512227.2003.tb00570.x)

Received 12 April 2011

Accepted 18 April 2011 